\title{
Endometrial cancer cell survival and apoptosis is regulated by protein kinase $\mathrm{C} \alpha$ and $\delta$
}

\author{
James M Haughian, Twila A Jackson, David M Koterwas and Andrew P Bradford
}

Division of Basic Reproductive Sciences, Department of Obstetrics and Gynecology, University of Colorado Health Sciences Center at Fitzsimons, Mail Stop 8309, PO Box 651112800 E. 19th Avenue, Aurora, Colorado 80045, USA

(Requests for offprints should be addressed to A P Bradford; Email: andy.bradford@uchsc.edu)

\begin{abstract}
Endometrial cancer is the most common invasive gynecologic malignancy but the molecular mechanisms underlying its onset and progression are poorly understood. Paradoxically, endometrial tumors exhibit increased apoptosis, correlating with disease progression and poor patient prognosis. Endometrial tumors also show altered activity and expression of protein kinase C (PKC) isoforms, implicated in the regulation of programmed cell death; however, PKC modulation of apoptosis in endometrial cancer cells has not been investigated. We detected nine out of ten PKC isoforms in Ishikawa endometrial cancer cell lines, and demonstrated expression of both PKC $\alpha$ and $\delta$ in human endometrial tumors. To determine the functional roles of PKC $\alpha$ and $\delta$ in apoptosis in endometrial cancer, Ishikawa cells were treated with selective PKC inhibitors or adenoviral constructs encoding wild-type or isoform-specific, dominant-negative mutants. Apoptosis was assessed by DNA fragmentation and caspase-mediated poly-(ADP-ribose)polymerase cleavage. The inhibition of $\mathrm{PKC} \delta$ suppressed etoposide-induced apoptosis, while overexpression of PKC $\delta$ enhanced it. In contrast, inhibition of PKC $\alpha$ elevated basal levels of apoptosis and potentiated etoposide-induced cell death. Etoposide treatment also selectively activated PKC $\delta$, but resulted in both cytosolic translocation and decreased activity of PKC $\alpha$. A fraction of $\mathrm{PKC} \delta$ also underwent caspase-dependent cleavage, in response to etoposide. Our results suggest that changes in apoptosis and PKC expression in endometrial cancer are mechanistically linked, such that $\mathrm{PKC} \delta$ is required for DNA damage-induced apoptosis, while $\mathrm{PKC} \alpha$ mediates a survival response. Thus, PKC $\alpha$ and $\delta$ expression and signaling may be important in endometrial tumorigenesis and could serve as potential prognostic indicators and/or novel targets for therapeutic intervention.
\end{abstract}

Endocrine-Related Cancer (2006) 13 1251-1267

\section{Introduction}

Endometrial cancer is the most common invasive gynecologic malignancy and the fourth most common cancer in women in the United States. In 2005, it was estimated that there would be over 40000 new cases and more than 7300 deaths (Jemal et al. 2005), making endometrial cancer an important health issue for women. Despite the large number of individuals affected by this disease, the molecular mechanisms involved in the pathophysiology of this gynecologic cancer remain largely unknown and understudied.

The protein kinase C (PKC) family of serine/threonine kinases has been shown to regulate a broad range of key cellular pathways including growth, survival, differentiation, and apoptosis (Fishman et al. 1998, Morse-Gaudio et al. 1998, Zeidman et al. 1999, Cross et al. 2000, Musashi et al. 2000, Ventura \& Maioli 2001, Brodie \& Blumberg 2003, Gutcher et al. 2003, Hofmann 2004). To date, at least ten PKC isoforms have been identified, which differ in their expression patterns, substrate specificity, and response to extracellular stimuli (Clemens et al. 1992, Lucas \& Sanchez-Margalet 1995, Jaken 1996, Nishikawa et al. 1997, Newton 2001). PKCs have been implicated in neoplastic transformation, the growth and metastasis of tumors, and response to therapy in a variety of tissues including breast, prostate, liver, colon, skin, stomach, and respiratory tract (Goodnight et al. 1994, Kiley 
et al. 1996, Cornford et al. 1999, Gomez et al. 1999, Spitaler et al. 1999, Watters \& Parsons 1999, Musashi et al. 2000, Koivunen et al. 2006). In endometrial cancers, the total PKC activity was significantly higher when compared with normal endometrial tissue (Fujimoto et al. 1995) and differential overexpression of PKC isoforms has been linked to the proliferative potential of endometrial cancer cell lines and tumor pathogenesis (Gretz et al. 1994, Bamberger et al. 1996, 1997, 1998, Fujimoto et al. 1996, Connor et al. 1997). In an analysis of endometrial tumors, $\mathrm{PKC} \alpha$ was more highly expressed in higher-grade endometrial tumors exhibiting lower levels of estrogen receptor $(E R \alpha)$ and poorer prognosis (Fournier et al. 2001). However, studies of PKC in endometrial tumors are limited, largely correlative, and the functional role of specific $\mathrm{PKC}$ isoforms in the pathophysiology of endometrial cancer has not been determined.

Specific PKC isoforms have also been shown to play a critical role in the regulation of apoptosis and may be either pro- or anti-apoptotic, dependent on cell type and stimulus (Leszczynski 1995, Lucas \& SanchezMargalet 1995, Whelan \& Parker 1998, Musashi et al. 2000, Brodie \& Blumberg 2003). Paradoxically, studies of endometrial tumors report an increase in apoptotic index during the progression from endometrial hyperplasia, through atypical endometrial hyperplasia, to endometrial adenocarcinoma (Ioffe et al. 1998). Moreover, undifferentiated and poorly differentiated endometrial carcinomas exhibited higher apoptotic indices when compared with well-differentiated tumors, and higher apoptotic indices correlated inversely with prognosis (Heatley 1997, Kokawa et al. 2001a). Thus, increased rates of apoptosis have been proposed to be a morphological indicator of potentially malignant endometrial tumors (Arends 1999, Stewart et al. 1999, Kokawa et al. 2001a).

Given the above evidence of aberrant apoptosis and changes in PKC expression in endometrial cancers and that PKCs modulate apoptosis in other tumors of epithelial origin, we investigated the potential role of $\mathrm{PKC}$ in the regulation of apoptosis in endometrial cancer cells. Herein, we provide evidence that PKC $\alpha$ and $\delta$ differentially regulate apoptosis and survival in Ishikawa endometrial cancer cells such that PKC $\delta$ is a critical mediator of apoptosis, while PKC $\alpha$ is important in cell survival. Our results demonstrate distinct functional roles for PKC $\alpha$ and $\delta$ in endometrial cancer cells and provide, for the first time, a potential mechanistic link between the reported changes in apoptotic index and PKC expression and/or activity, concomitant with progression from hyperplasia to malignancy in the endometrium.

\section{Materials and methods}

\section{Cell culture}

Ishikawa endometrial adenocarcinoma cells were a generous gift from Dr K K Leslie (University of New Mexico, Albuquerque, NM, USA). Cells were grown in Dulbecco's modified Eagle's Medium (DMEM) supplemented with $12.5 \%$ horse serum, $2.5 \%$ fetal calf serum, $10 \mathrm{units} / \mathrm{ml}$ penicillin, $10 \mu \mathrm{g} / \mathrm{ml}$ streptomycin, and $200 \mu \mathrm{M}$ L-glutamine and maintained at $37{ }^{\circ} \mathrm{C}$ in $5 \% \mathrm{CO}_{2}$ in air. Before treatment, the cells were serum-deprived overnight by culturing in DMEM without added serum. Drugs used in experiments were solubilized in dimethyl sulphoxide (DMSO). Etoposide, rottlerin, Gö6976, phorbol ester (TPA), and benzyloxycarbonyl-Val-Ala-Asp (OMe) fluoromethylketone (Z-VAD-FMK) were purchased from Calbiochem (San Diego, CA, USA).

\section{Western blot analysis}

The cells were harvested by washing twice in ice-cold PBS and lysing them in $150 \mu \mathrm{l}$ buffer $(50 \mathrm{mM}$ Tris ( $\mathrm{pH}$ 7.4), $150 \mathrm{mM} \mathrm{NaCl}, 0.5 \%$ Triton $\mathrm{X}-100$ ) supplemented with protease inhibitor cocktail (Roche Diagnostics). Lysate protein concentrations were determined using the Bradford assay (Bio-Rad Laboratories) and an equal volume of Laemmli sample buffer (20\% glycerol, $2 \%$ (w/v) SDS, 5\% $\beta$-mercaptoethanol, $62.5 \mathrm{mM}$ Tris ( $\mathrm{pH}$ $6.8), 1 \%(\mathrm{w} / \mathrm{v})$ bromophenol blue dye) was added. Between 20 and $75 \mu \mathrm{g}$ total cellular protein was resolved by electrophoresis on $10 \%$ polyacrylamideSDS gels in electrophoresis buffer $(25 \mathrm{mM}$ Tris $(\mathrm{pH}$ 8.3), $192 \mathrm{mM}$ glycine, $0.1 \%$ (w/v) SDS), transferred to polyvinylidene difluoride (PVDF) membrane in transfer buffer (25 mM Tris (pH 8.3), $192 \mathrm{mM}$ glycine), and probed using specific antibodies. The PKC antibodies used for immunoblotting include PKC $\alpha$ (sc-208), PKC $\beta$ (sc-209), PKC $\beta I I$ (sc-210), PKC $\delta$ (sc-937), PKC $\varepsilon$ (sc-214), $\mathrm{PKC} \gamma$ (sc-211), $\mathrm{PKC} \eta$ (sc-215), $\mathrm{PKCl} / \lambda$ (sc-1091), PKC $\theta$ (sc-212), PKC $\zeta$ (sc-216), and secondary anti-rabbit (sc-2004) or anti-mouse (sc-2005) IgG-HRP antibodies were obtained from Santa Cruz Biotechnology (Santa Cruz, CA, USA). The poly(ADP-Ribose)-polymerase (PARP) cleavage fragmentspecific antibody was purchased from BD Biosciences Pharmingen (San Jose, CA, USA). The actin loading controls were assessed using a monoclonal anti- $\beta$-actin (A5316) antibody (Sigma). The primary antibody binding was visualized using species-specific secondary antibody conjugated to HRP, chemiluminescent substrate, and exposure to autoradiographic film. The molecular weight of proteins was estimated by 
comparison with the Full Range Rainbow recombinant protein molecular weight marker from Amersham Biosciences. Quantitation of band intensity was performed by densitometry using Quantity One software (v. 4.5.1) and a GelDoc imaging system (Bio-Rad).

\section{Immunohistochemistry}

Endometrial tumor tissue that had been formalin-fixed and paraffin-embedded was obtained from the Department of Pathology at the University of Colorado Health Science Center. The tissue was sectioned into $5 \mu \mathrm{m}$ thick slices and blocked for endogenous peroxidase activity using 3\% hydrogen peroxide. Antigen retrieval was performed in citrate buffer $(20 \mathrm{mM}, \mathrm{pH}$ 6.0) for $10 \mathrm{~min}$ at $60{ }^{\circ} \mathrm{C}$. The sections were incubated with antibodies specific for PKC $\delta(\mathrm{C}-20,0.17 \mu \mathrm{g} / \mathrm{ml})$ and $\mathrm{PKC} \alpha(\mathrm{H}-7,1.275 \mu \mathrm{g} / \mathrm{ml})$, and stained using an indirect avidin biotin immunoperoxidase method on a DAKO Autostainer (DakoCytomation, Carpinteria, CA, USA) as described (Tringler et al. 2006). The specificity of staining was verified using subclassmatched IgG1 (BD PharMingen) in place of PKC antibodies and through blocking studies with peptide antigen (Santa Cruz Biotechnology).

\section{Chromatin condensation and DNA fragmentation assay}

Nuclear DNA in healthy and apoptotic cells was stained using Hoechst 33342 dye as described (Mpoke $\&$ Wolfe 1997). Ishikawa cells were plated on glass cover slips in serum-containing media and allowed to adhere before treatments. Following treatment of cells, the cover slips were washed twice in PBS so that only the adherent cells remained. After the PBS washes, the cells were covered for $5 \mathrm{~min}$ with a solution containing $5 \mu \mathrm{g} / \mathrm{ml}$ Hoechst 33342 dye from Sigma. Following staining, the cells were washed a final time in PBS and the stained nuclei were examined at $10 \times$ magnification under u.v. light. The proportion of apoptotic cells was determined by counting cells in four random fields per condition in three separate experiments. Quantiation of extranuclear fragmented DNA was performed using the Cell Death Detection ELISA kit as per the manufacturer's recommended protocol (Roche).

\section{Adenoviral vectors}

PKC adenoviral constructs were a generous gift of Drs Lee Carpenter and Trevor Biden (Garvan Institute of Medical Research, St Vincent's Hospital, Sydney,
Australia) and Dr Mary Reyland (University of Colorado Health Sciences Center, Denver, CO, USA). Information pertaining to the creation and use of these constructs in other cell types has been published previously (Reyland et al. 1999, Carpenter et al. 2002). Dominant-negative PKC constructs were created by introducing a single amino acid mutation in the ATPbinding site of the catalytic domain, specifically a (K376R) mutation in PKC $\delta$ from rat and (K368R) mutation in $\mathrm{PKC} \alpha$ from mouse. For adenovirus infections, $3.0 \times 10^{6}$ cells were plated on $60 \mathrm{~mm}$ dishes and allowed to adhere for $18 \mathrm{~h}$ or more. After removing the serum-containing media, adenovirus was added to the adherent cells in $1 \mathrm{ml}$ serum-free media at a predetermined multiplicity of infection (MOI) based on viral titer. The plates were gently agitated every $10 \mathrm{~min}$ for $1 \mathrm{~h}$, then serum free media was added to a final volume of $3 \mathrm{ml}$. The infected cells were then incubated for 18-24 $\mathrm{h}$ in the serum-free media to enable adequate protein expression before drug treatments.

\section{Immunoprecipitations and PKC kinase assays}

Immunoprecipitations were performed using protein A/G PLUS-agarose beads from Santa Cruz. PKC kinase assays included PKC lipid activator from Upstate (Lake Placid, NY, USA), histone (Sigma), and $\left[\gamma-{ }^{32} \mathrm{P}\right]$ ATP (Amersham). The cells were harvested by washing once in ice-cold PBS and lysing cells in lysis buffer (25 mM HEPES (pH 7.5), 0.3 M $\mathrm{NaCl}, 1.5 \mathrm{mM} \mathrm{MgCl}_{2}, 0.2 \mathrm{mM}$ EDTA (pH 8.0), $0.5 \mathrm{mM}$ dithiothreitol, $0.1 \%$ Triton X-100) amended at each use with phosphatase and protease inhibitors (20 mM $\beta$-glycerophosphate, $0.1 \mathrm{mM}$ sodium orthovanadate, $10 \mathrm{mM}$ sodium fluoride, $1 \mathrm{mM}$ phenylmethylsulphonyl fluoride, and protease inhibitor cocktail). Cell lysates were vortexed and frozen before clearing insoluble cell debris by centrifugation at $14000 \mathrm{~g}$ for $10 \mathrm{~min}$ at $4{ }^{\circ} \mathrm{C}$. The total cellular protein was quantitated and $1000 \mu \mathrm{g}(\mathrm{PKC} \alpha)$ or $500 \mu \mathrm{g}$ $(\mathrm{PKC} \delta)$ total cellular protein was combined with $5 \mu \mathrm{g}$ PKC $\alpha$ (sc-208) or $\mathrm{PKC} \delta$ (sc-937) primary antibody in a total volume of $300 \mu$ l. After agitating overnight at $4{ }^{\circ} \mathrm{C}$, protein $\mathrm{A} / \mathrm{G}$ agarose beads were added as recommended and agitated with the samples for $2 \mathrm{~h}$. The immune complexes were pelleted and washed four times in lysis buffer. After the final lysis buffer wash, the pellet was washed twice in kinase assay buffer (40 mM Tris ( $\mathrm{pH} 7.4$ ), $20 \mathrm{mM} \mathrm{MgCl}_{2}$, $20 \mu \mathrm{M}$ ATP, $2.5 \mathrm{mM} \mathrm{CaCl}_{2}$ ). The final pellet was resuspended in $22 \mu \mathrm{l}$ kinase assay buffer and a $2 \mu \mathrm{l}$ aliquot of the suspension was acquired to be used as a loading control by western blotting. The final reaction 
was performed in a $40 \mu \mathrm{l}$ volume containing the resuspended immunoprecipitates, $5 \mu \mathrm{l}$ PKC lipid activator, $20 \mu \mathrm{g}$ histone, and $5 \mu \mathrm{Ci}\left[\gamma^{-32} \mathrm{P}\right]$ ATP. Before addition to the reaction, the PKC lipid activator containing $0.05 \mathrm{mg} / \mathrm{ml}$ phosphatidylserine and $0.05 \mathrm{mg} / \mathrm{ml}$ diacylglycerol was sonicated on ice for $30 \mathrm{~s}$. All reaction components were combined on ice and then moved to a $30{ }^{\circ} \mathrm{C}$ water bath. After $20 \mathrm{~min}$, the reactions were immediately placed on ice and Laemmli sample buffer was added before heating the samples for $5 \mathrm{~min}$ at $95{ }^{\circ} \mathrm{C}$. Phosphorylated histone protein was visualized by electrophoresis on a $12.5 \%$ polyacrylamide gel followed by drying and exposing the gel to film. Quantitation of radioactivity in each band was determined using a Storm 860 PhosphorImager and ImageQuant software (Molecular Dynamics, Sunnyvale, CA, USA).

\section{Cell fractionation}

Soluble and particulate cell fractions were isolated as described (Jackson et al. 2001), briefly, after treatment adherent cells were washed twice in ice-cold PBS and harvested in lysis buffer A (20 mM Tris ( $\mathrm{pH} \mathrm{7.5),}$ $2 \mathrm{mM}$ EDTA, $2 \mathrm{mM}$ EGTA, $1 \mathrm{mM}$ PMSF, 0.1\% $\beta$-mercaptoethanol, and protease inhibitor cocktail) using a cell scraper. The cells were then sonicated for $10 \mathrm{~s}$ (output 4, constant duty cycle) using a Branson Sonicator (Branson Ultrasonics Corp., Danburg, CT, USA) and pelleted at $70000 \mathrm{~g}$ for $1.5 \mathrm{~h}$. The supernatant (soluble fraction) was removed to a new tube and the remaining pellet was resuspended in lysis buffer B (lysis buffer A+1\% Triton X-100) by sonicating for $10 \mathrm{~s}$. Following sonication, the sample was pelleted again by centrifugation at $13000 \mathrm{~g}$ for $15 \mathrm{~min}$ at $4{ }^{\circ} \mathrm{C}$ and the supernatant harvested as the Triton-soluble, particulate fraction.

\section{Statistical analysis}

Values shown in figures are given as the mean \pm s.D. or S.E.M. The data were analyzed using a paired Student's $t$-test. $P$ values $<0.05$ were considered significant.

\section{Results}

Ishikawa cells are derived from a well-differentiated endometrial tumor (Nishida et al. 1996, Leslie et al. 1997) and retain expression of both estrogen and progesterone receptors (Dai et al. 2002). They represent the most widespread and well-characterized human cell-based model for endometrial cancer and have been used extensively to elucidate molecular mechanisms of hormone action, signal transduction pathways, and tumorigenesis (Vollmer 2003). Expression of PKC isoforms was determined by western blot analysis using isoform-specific antibodies (Santa Cruz Biotechnology). As shown in Fig. 1A, Ishikawa cells express the conventional isoforms PKC $\alpha, \beta$ II, and $\gamma$; novel PKCs $\delta, \varepsilon, \eta$, and $\theta$; and the atypical PKC $\zeta$. The conventional PKC $\beta I$ was present at low levels, detectable after prolonged exposure, and the atypical PKC isoform $\mathrm{t} / \lambda$ was not detected. $\beta$-Actin was used a loading control.

$\mathrm{PKC} \alpha$ is the predominant isoform associated with cell survival or suppression of apoptosis (Whelan \& Parker 1998, Li et al. 1999, Deng et al. 2001). Its expression has previously been shown in partially purified extracts of endometrial tumors (Tonetti et al. 2000) and linked to estrogen-dependent proliferation (Tonetti et al. 1998, Wu et al. 2005). PKC $\delta$, the predominant pro-apoptotic isoform in other epithelial cell types (Basu 2003, Brodie \& Blumberg 2003, Gutcher et al. 2003), was expressed in EnCa101 endometrial cancer cells (Tonetti et al. 1998); however, its expression had not been shown in endometrial tumors. Using immunohistochemistry, we observed the expression of both PKC $\alpha$ and $\delta$ in paraffin sections of human endometrial tumors and normal tissue. PKC $\alpha$ and $\delta$ were detected in each of the 24 samples of endometrial tumors and in each of the eight sections derived from proliferative, secretory, and atrophic normal endometrium (Fig. 1B and C; data not shown). Given their functional role in modulating apoptosis in numerous epithelial cell types (Brodie \& Blumberg 2003, Gutcher et al. 2003, Hofmann 2004) and expression in human endometrial tumors, we hypothesized that $\mathrm{PKC} \alpha$ and $\delta$ are important regulators of apoptosis in endometrial cancer.

To address the functional roles of PKC $\alpha$ and $\delta$ in regulating apoptosis in endometrial cancer cells, we utilized selective PKC inhibitors and determined their effects on etoposide-induced apoptosis, assessed by changes in cell morphology, DNA fragmentation, and caspase activation. The topoisomerase II inhibitor etoposide has been used as a chemotherapeutic agent in endometrial cancer (Poplin et al. 1999), and is a potent inducer of DNA damage and apoptosis (Ruvolo et al. 1998). First, Ishikawa cells were stained with Hoechst fluorescent dye 33342, which is indicative of membrane disruption, organelle acidification, and chromatin condensation characteristic of the initial stages of apoptosis (Mpoke \& Wolfe 1997, Chen et al. 2005, Wada et al. 2005). Cells were visualized under u.v. and visible light and results quantitated by counting multiple fields. Under basal conditions, approximately $24 \%$ of Ishikawa cells stained positive 
A

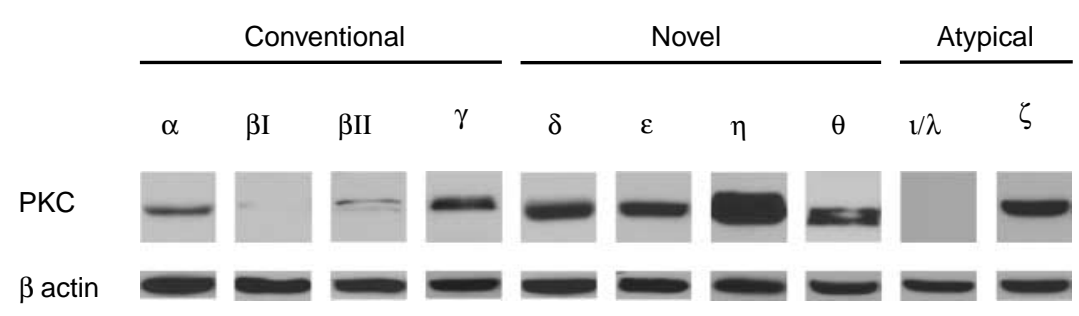

B

Immunohistochemistry of PKC $\alpha$
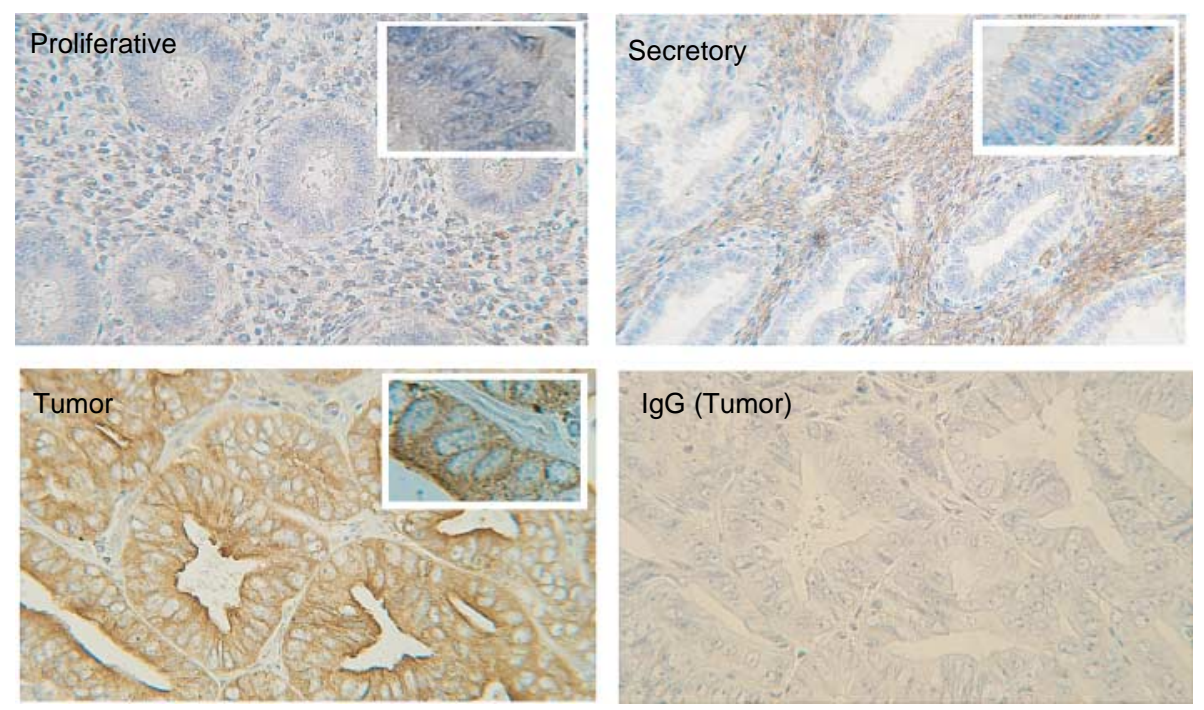

C

Immunohistochemistry of PKC $\delta$
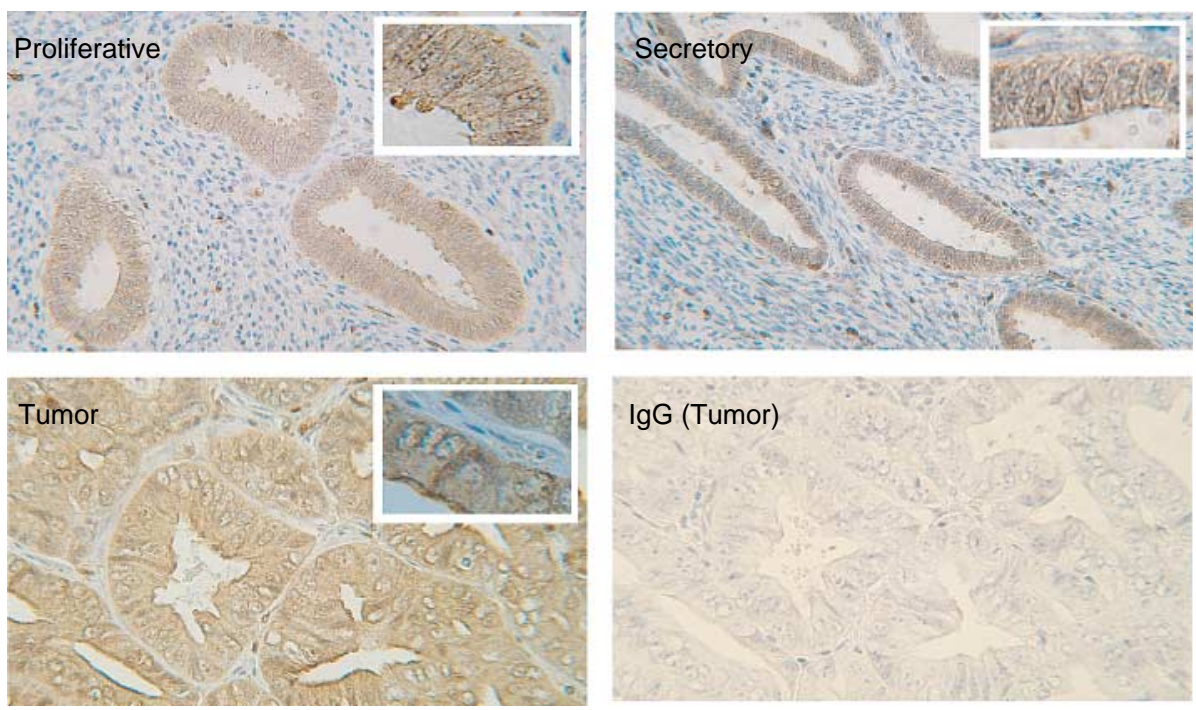

Figure $1 \mathrm{PKC}$ isoform expression profile in Ishikawa endometrial cancer cell line. (A) Cell extracts were probed with the indicated isoform-specific PKC antibodies. Uniform protein loading was confirmed by blotting for $\beta$-actin. (B) and (C) Immunohistochemical staining of (B) PKC $\alpha$ and (C) PKC $\delta$ in normal secretory and proliferative endometrium and a pathological grade II, endometrial tumor. Representative images were acquired from the same location within a single tumor. Larger fields are magnified $16 \times$, inset $25 \times$. IgG is included as a control for non-specific immunostaining. 
(Fig. 2A). Treatment with $50 \mu \mathrm{M}$ etoposide increased the fraction of Hoechst 33342 staining cells to over $43 \%$. To determine the roles of PKC $\alpha$ and $\delta$, we utilized the PKC inhibitors Gö6976 and rottlerin, which are selective for the conventional PKCs $(\alpha, \beta I$, $\beta I I$, and $\gamma$ ) and PKC $\delta$ respectively (Gschwendt et al. 1994, Keenan et al. 1997). As indicated in the representative fields (Fig. 2A) and associated quantitation (Fig. 2B), pretreatment with rottlerin had no effect on basal apoptosis in Ishikawa cells but significantly reduced the proportion of Hoechst 33342-positive cells in response to etoposide from 43 to $32 \%$. In contrast, treatment with Gö6976 alone increased the basal apoptotic index from 23.9 to $29.1 \%$ and potentiated the effect of a lower submaximal dose $(10 \mu \mathrm{M})$ of etoposide (Fig. 2C), significantly increasing the fraction of apoptotic cells from 31 to $47 \%$. These results suggest that the inhibition of PKC $\delta$ attenuated etoposide-induced apoptosis in endometrial cancer cells, whereas inhibition of conventional PKCs
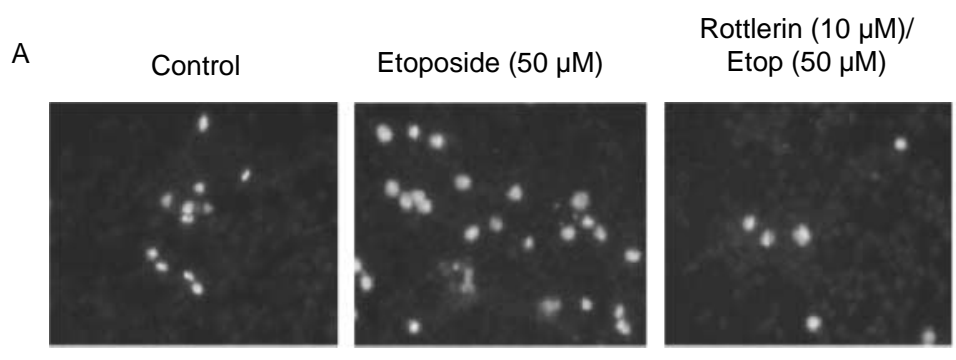

Etop $(10 \mu \mathrm{M})$

B

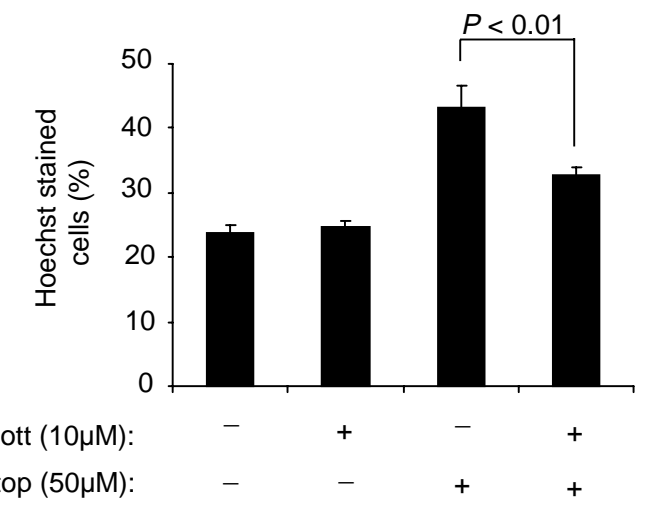

C

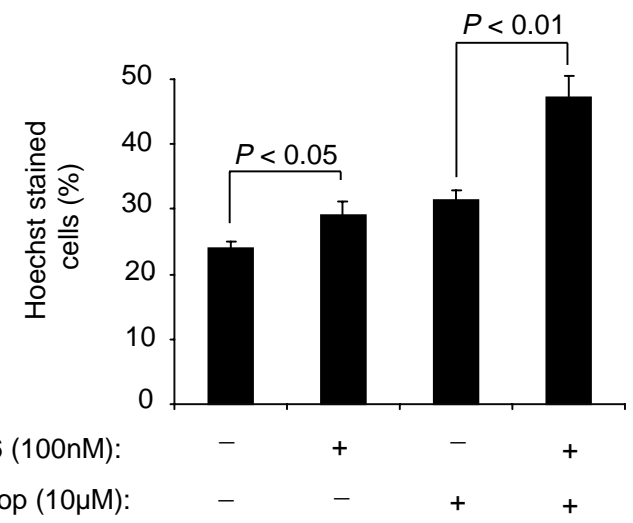

Figure 2 PKC inhibitors regulate etoposide-induced apoptosis. Ishikawa cells were pretreated for 30 min with pharmacological inhibitors rottlerin (PKC $\delta$-selective inhibitor) and Gö6976 (conventional PKC inhibitor) to block kinase activity during etoposide treatment. Cellular apoptosis was assessed $24 \mathrm{~h}$ later by Hoechst 33342 staining of condensed nuclear chromatin and representative fields of select treatments are shown in A. Bar graphs depict the proportion of apoptotic cells following treatments with rottlerin and $50 \mu \mathrm{M}$ etoposide (B), or Gö6976 and a lower $(10 \mu \mathrm{M})$ dose of etoposide (C). The proportion of apoptotic cells was determined by dividing the number of positive cells by the total number of cells in a field. Results shown are mean \pm S.E.M. derived from counting four fields per treatment, in three separate experiments. 
increased basal levels of apoptosis and enhanced the response to etoposide.

To corroborate our results obtained by Hoechst staining, we examined the effects of PKC inhibitors on etoposide-induced DNA fragmentation using a Cell Death Detection ELISA kit (Roche) that quantifies the amount of low molecular weight, histone-bound DNA in the cytoplasm, characteristic of cells undergoing apoptosis (Reyland et al. 1999). As shown in Fig. 3, treatment of Ishikawa cells with etoposide resulted in an increase in DNA fragmentation. Again, consistent with PKC $\delta$ being pro-apoptotic, pretreatment with rottlerin markedly reduced DNA fragmentation in a dose-dependent manner (Fig. 3A). Conversely, pretreatment of cells with Gö6976 enhanced the amount of DNA fragmentation detectable after etoposide treatment (Fig. 3B). Neither inhibitor alone significantly affected DNA fragmentation in this assay. Thus, Ishikawa cells treated with rottlerin, a $\mathrm{PKC} \delta$-selective inhibitor, showed a reduced apoptotic response to etoposide, suggesting that $\mathrm{PKC} \delta$ is pro-apoptotic. In contrast, Gö6976 enhanced etoposide-induced apoptosis, suggesting a pro-survival role for conventional PKC isoforms.

Gö6976 does not distinguish between the conventional PKC isoforms $(\alpha, \beta$, and $\gamma)$, and, despite its widespread use, concern has been expressed regarding the specificity of rottlerin in vitro (Davies et al. 2000). Thus, in order to more specifically manipulate cellular activities of PKC $\alpha$ and $\delta$, we used adenoviral expression constructs expressing wild-type (WT) or dominant-negative (DN), kinase dead forms of these enzymes that have been shown to increase or suppress endogenous isoform-specific PKC activity respectively
A

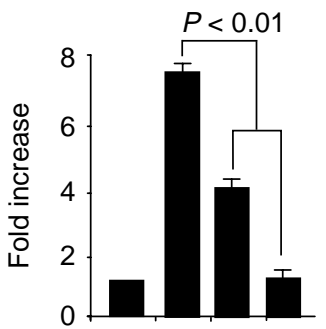

Rott $(\mu \mathrm{M}): 10-10 \quad 10$

Etop $(\mu \mathrm{M}):-505050$
B

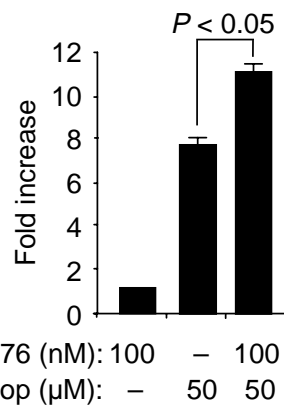

Figure 3 PKC inhibitors modulate DNA fragmentation. Ishikawa cells were pretreated for 30 min with the PKC $\delta$ inhibitor rottlerin (A) or PKC $\alpha$ inhibitor Gö6976 (B) before treatment with etoposide $(50 \mu \mathrm{M})$. After $24 \mathrm{~h}$, internucleosomal DNA fragmentation, a hallmark of apoptosis, was assayed and quantified using the Cell Death Detection kit (Roche) as per the manufacturer's protocol. The results are expressed as fold change in absorbance relative to etoposide-treated cells; mean \pm S.E.M. of three experiments.
(Reyland et al. 1999, 2000). Cleavage of PARP, an essential DNA repair enzyme, is another hallmark indicator of cells undergoing apoptosis. PARP becomes inactivated when the apoptotic effector caspase- 3 and caspase-7 cleave the full-length PARP protein $(116 \mathrm{kDa})$ releasing an $89 \mathrm{kDa}$ fragment (Soldani \& Scovassi 2002). Western blotting to detect the appearance of the $89 \mathrm{kDa}$ PARP cleavage fragment has thus been used as an indirect assay of intracellular caspase-3 and caspase-7 activity (Yu et al. 2001).

As shown in Fig. 4A, $48 \mathrm{~h}$ following transduction with adenovirus at the specified MOI of 50, both wildtype and dominant-negative PKC were overexpressed relative to the level of endogenous $\mathrm{PKC} \delta$ evident in cells infected with GFP adenovirus as a control (Fig. 4A). Etoposide treatment did not significantly affect expression of endogenous or adenoviral PKC $\delta$ expression. Figure 4B shows Ishikawa cell extracts, treated with or without etoposide and probed for the PARP cleavage fragment. In cells transduced with WT PKC $\delta$ adenovirus, a marked increase in basal PARP cleavage, relative to green fluorescent protein (GFP) control is observed (Fig. 4B and C) reaching levels comparable with that observed in GFP cells treated with $50 \mu \mathrm{M}$ etoposide. Furthermore, overexpression of PKC $\delta$ significantly enhanced PARP cleavage induced by etoposide. Conversely, expression of dominantnegative PKC alone suppressed any detectable basal PARP cleavage when compared with GFP controls and significantly attenuated the effects of etoposide (Fig. 4B and C). Of note, the PKC $\delta$ WT and DN constructs differ in only one amino acid and were expressed at similar levels. Thus, it is unlikely that the observed effects are a consequence of non-specific viral toxicity.

To confirm the apparent synergistic pro-apoptotic effect of $\mathrm{PKC} \delta$ overexpression in combination with etoposide, Ishikawa cells infected at a constant MOI were challenged with increasing doses of etoposide (Fig. 4D). Consistent with our initial experiment (Fig. 4B and C), overexpression of PKC $\delta$ alone induced PARP cleavage and this effect was increased by etoposide in a dose-dependent manner. PARP cleavage in GFP adenovirus transduced control cells was not detectable until treatment with $25 \mu \mathrm{M}$ etoposide, while cells overexpressing $\mathrm{PKC} \delta$ exhibited increased apoptotic PARP cleavage in the presence of only $2 \mu \mathrm{M}$ etoposide. As a control, expression of dominant-negative $\mathrm{PKC} \delta$ considerably suppressed PARP cleavage at both 25 and $50 \mu \mathrm{M}$ doses of the etoposide (Fig. 4D). These results are completely consistent with observations using PKC inhibitors 
A

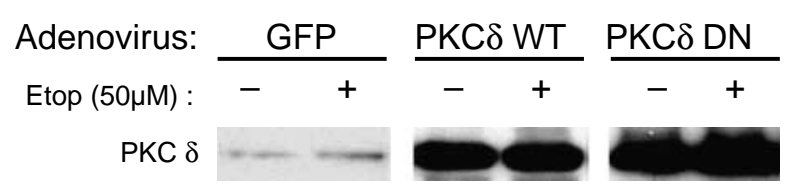

B

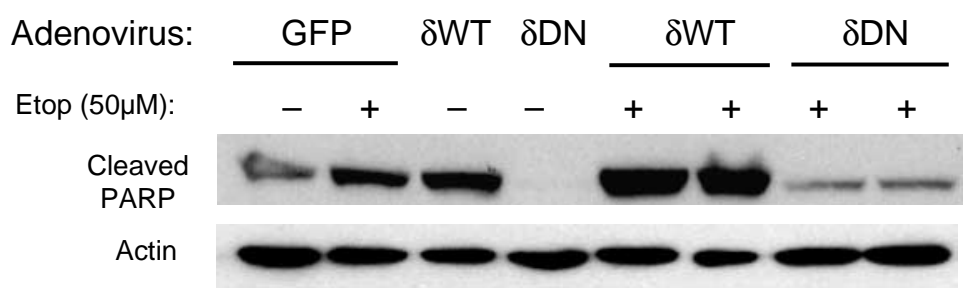

C

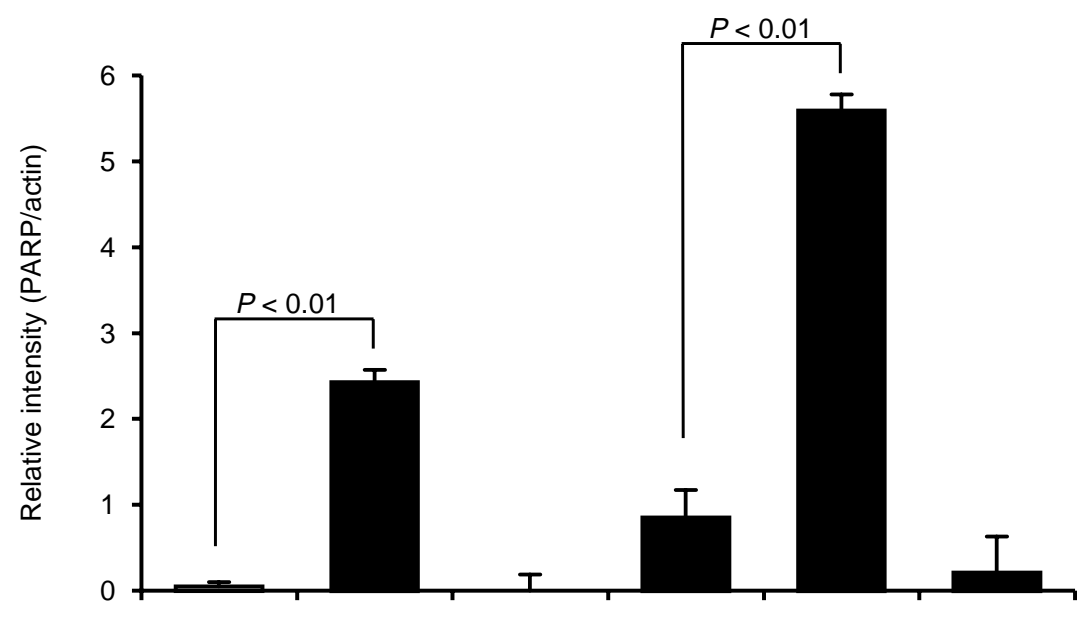

$\begin{array}{rcccccc}\text { Adenovirus: } & \text { GFP } & \delta W T & \delta D N & \text { GFP } & \delta W T & \delta D N \\ \text { Etop }(50 \mu \mathrm{M}): & - & - & - & + & + & +\end{array}$

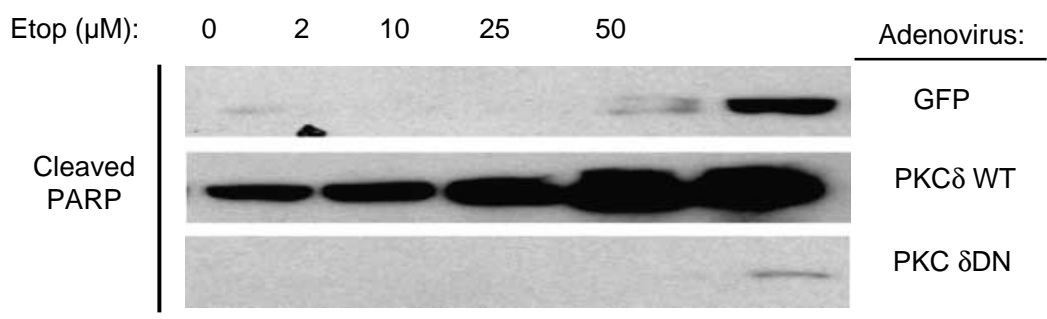

Figure 4 Overexpression of wild-type PKC $\delta$ induces apoptosis, whereas dominant-negative PKC $\delta$ is protective. Ishikawa cells were infected at an $\mathrm{MOI}$ of 50 with adenoviral constructs encoding wild-type PKC $\delta(\delta W T)$, dominant-negative PKC $\delta$ ( $\delta \mathrm{DN})$, or green fluorescent protein (GFP) as control. One day following infection, these cells were challenged with $50 \mu \mathrm{M}$ etoposide and harvested $24 \mathrm{~h}$ later. The western blot in $(\mathrm{A})$ depicts adenovirally mediated overexpression of PKC $\delta$ protein relative to the level of endogenous expression seen in GFP-infected controls. In (B), representative western blot using an antibody that specifically recognizes the $89 \mathrm{kDa}$ cleavage fragment of PARP protein produced by activated caspases. (C) Western blots of cleaved PARP and actin from four separate experiments were quantitated by densitometry. Data presented are the ratio of intensity between cleaved PARP and $\beta$-actin respectively, from the same western blot. Values are mean \pm s.E.M. (D) Ishikawa cells were infected as described and challenged with increasing concentrations of etoposide as indicated. Equal amounts of protein $(50 \mu \mathrm{g})$ were loaded and cellular apoptosis was again determined by blotting specifically for the PARP cleavage fragment. 


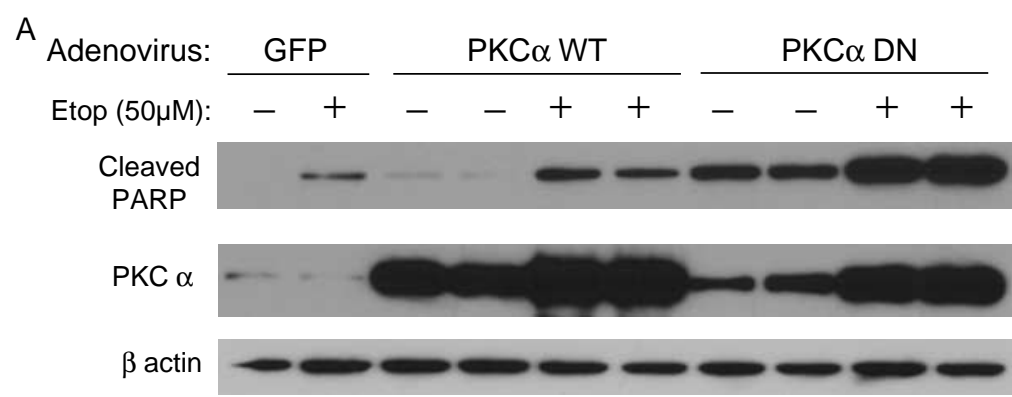

B

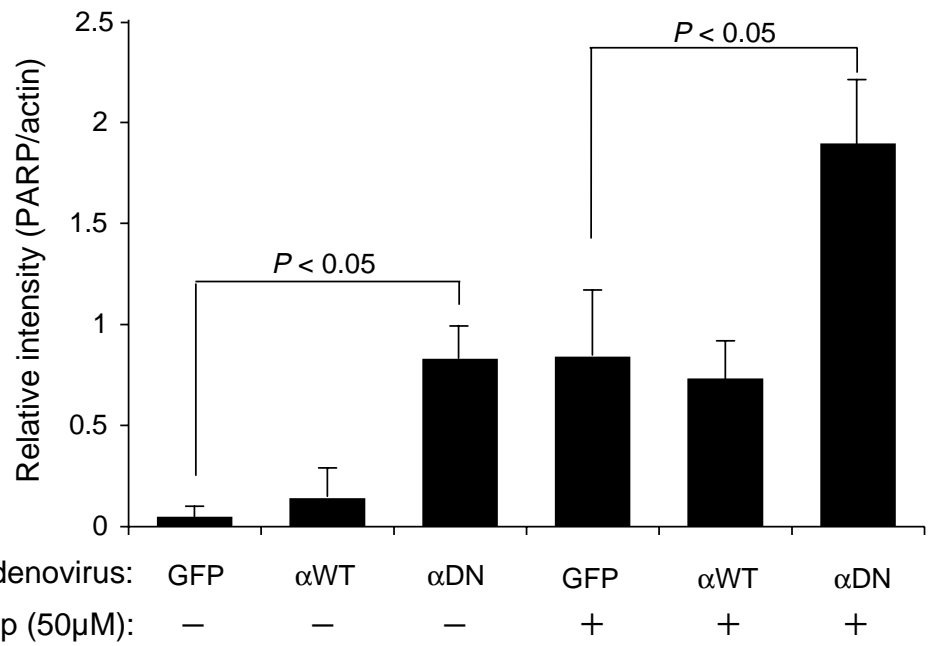

C

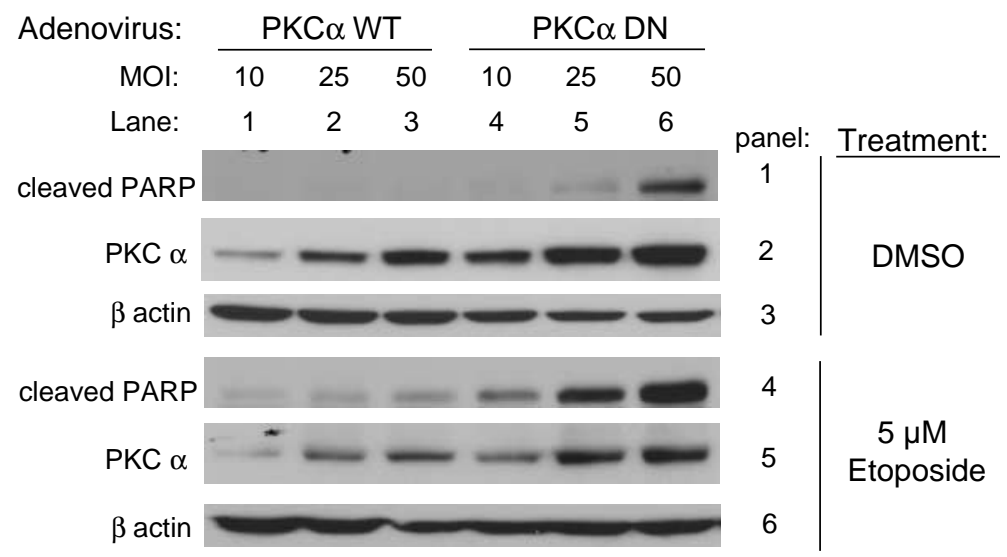

Figure 5 Overexpression of dominant-negative PKC $\alpha$ enhances etoposide-induced apoptosis. Ishikawa cells were infected at an $\mathrm{MOI}$ of 50 with adenoviral constructs encoding wild-type PKC $\alpha(\alpha \mathrm{WT})$, dominant-negative PKC $\alpha(\alpha \mathrm{DN})$, or green fluorescent protein (GFP) as control. One day following infection, the cells were challenged with $50 \mu \mathrm{M}$ etoposide and harvested for western blot $24 \mathrm{~h}$ later. The representative western blots in $(\mathrm{A})$ depict the level of cellular apoptosis as determined by Western blotting with an antibody that specifically recognizes the $89 \mathrm{kDa}$ cleavage fragment of PARP protein produced by activated caspases. Also shown in $(A)$ is the level of adenovirally mediated overexpression of $P K C \alpha$ protein relative to the level of endogenous expression seen in GFP-infected controls. $\beta$-Actin serves as a control for equal protein loading. (B) Western blots from four separate experiments were quantitated by densitometry. Data presented are the ratio of intensity between cleaved PARP and $\beta$-actin respectively, from the same western blot. Values are mean \pm s.E.M. (C) PARP cleavage in Ishikawa cells infected with PKC $\alpha$ adenoviral constructs at an increasing $\mathrm{MOI}$ in combination with a low dose $(5 \mu \mathrm{M})$ of etoposide. 
and suggest that $\mathrm{PKC} \delta$ is a critical component of the pro-apoptotic pathway in endometrial cancer cells.

To determine the role of $\mathrm{PKC} \alpha$ in etoposidemediated apoptosis, Ishikawa cells were infected with adenoviral constructs encoding wild-type or dominantnegative kinase $(\mathrm{PKC} \alpha \mathrm{DN})$. GFP adenovirus was again used as a control. Increased PARP cleavage was apparent in untreated cells overexpressing dominant-negative PKC $\alpha$ relative to the level of basal apoptosis seen in control Ishikawa cells expressing GFP (Fig. 5A). Following etoposide treatment, PARP cleavage was increased to a greater degree in cells overexpressing dominant-negative $\mathrm{PKC} \alpha$, suggesting that inhibition of $\mathrm{PKC} \alpha$ sensitized the cells to etoposide-induced apoptosis. Overexpression of wildtype PKC $\alpha$, however, elicited no change in PARP cleavage relative to GFP control cells treated with etoposide. Thus, while endogenous $\mathrm{PKC} \alpha$ activity is clearly an important mediator of cell survival, increased PKC $\alpha$ expression was not sufficient to confer resistance to etoposide.

It is evident that $50 \mu \mathrm{M}$ etoposide treatment apparently increased the level adenoviral PKC $\alpha$ expression (Fig. 5A, panel 2), possibly due to increased viral promoter activity or protein stabilization. No significant change in endogenous levels of $\mathrm{PKC} \alpha$, in response to etoposide, was observed. However, since both wild-type and dominant-negative constructs are affected, the observed effects on apoptosis cannot be attributed to non-specific effects of viral protein overexpression. Nevertheless, to further confirm the role of $\mathrm{PKC} \alpha$, we conducted a second experiment where the Ishikawa cells were challenged with a tenfold lower dose of etoposide $(5 \mu \mathrm{M})$ and infected with adenovirus at an increasing MOI $(10,25,50)$. As seen in Fig. 5C, panels 2 and 4, infecting cells with wild-type or dominant-negative PKC $\alpha$ adenovirus at increasing MOI resulted in the expected dosedependent increase in the level of PKC $\alpha$ protein, but the lower dose of etoposide did not influence virally mediated PKC $\alpha$ expression. In vehicle-treated cells expressing dominant-negative PKC $\alpha$, PARP cleavage increased in a MOI-dependent fashion (panel 1; lanes 4-6), whereas no increase in PARP cleavage was apparent in cells overexpressing wild-type PKC $\alpha$ (panel 1; lanes 1-3). Treatment of cells overexpressing $\mathrm{PKC} \alpha$, with $5 \mu \mathrm{M}$ etoposide, induced minimal PARP cleavage, which was not affected by increased expression of PKC $\alpha$ (panel 4; lanes 1-3). In contrast, etoposide resulted in a robust, MOI-dependent, increase in PARP cleavage in cells expressing dominant-negative PKC $\alpha$, over and above levels induced by expression of dominant-negative PKC $\alpha$
A

PKC $\delta$ Activity

\begin{tabular}{ccccc}
\multicolumn{4}{c}{ Minutes after etoposide treatment } \\
\hline 0 & 15 & 30 & 60 & 120
\end{tabular}
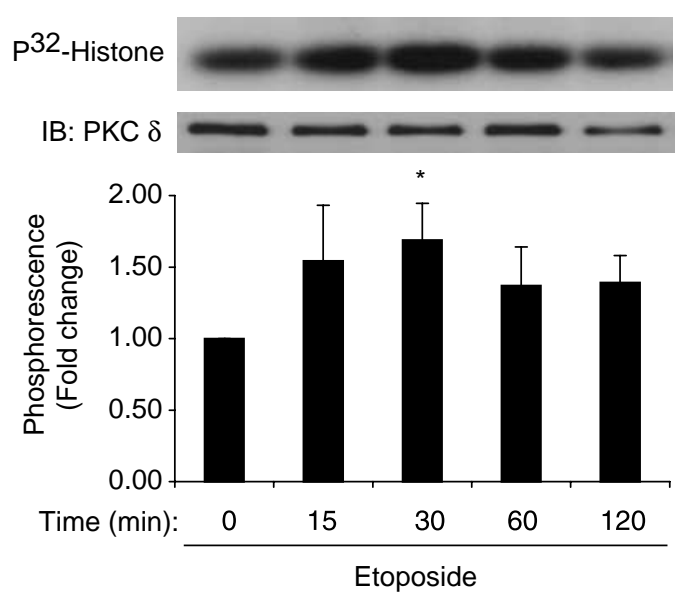

B

PKC $\alpha$ Activity

Minutes after etoposide treatment

$\begin{array}{lllll}0 & 15 & 30 & 60 & 120\end{array}$

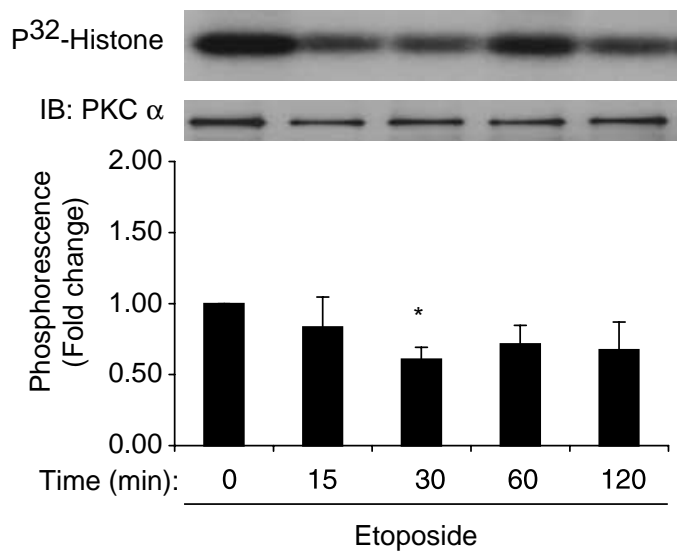

Figure 6 In vitro kinase assay of PKC $\delta$ and $\alpha$ activities following etoposide treatment. Ishikawa cells treated with $50 \mu \mathrm{M}$ etoposide or 100 nM TPA were harvested at the times indicated. In (A), top panel is an autoradiograph of histone protein phosphorylated by PKC $\delta$ immunoprecipitated from $500 \mu \mathrm{g}$ total cellular protein. The kinase activity in the immunoprecipitate was determined by co-incubation at $30{ }^{\circ} \mathrm{C}$ for 20 min with radiolabeled ATP, lipid co-activators (phosphatidyl serine, diacylglycerol), and histone as substrate. Uniform immunoprecipitation of PKC $\delta$ and $\alpha$ at each time point was verified by western blotting. (B) Equivalent conditions to $(A)$ except that $P K C \alpha$ protein was immunoprecipitated from $1000 \mu \mathrm{g}$ of total cellular protein. Quantitation of radioactivity in each experiment was determined using a phosphorimager. Values are normalized as a proportion of activity at $0 \mathrm{~min}$ and are presented as mean \pm S.E.M. of three separate experiments ${ }^{*} P<0.05$. 
alone (compare panels 1 and 4; lanes 3-6), indicating that inhibition of $\mathrm{PKC} \alpha$ dramatically sensitized the cells to this DNA damaging agent.

In summary, apoptotic PARP cleavage in untreated and etoposide-treated Ishikawa cells was consistently increased by expression of dominant-negative PKC $\alpha$, while overexpression of the wild-type kinase had no apparent effects. Considering our results from both the pharmacological inhibitors and the adenoviralmediated overexpression, we conclude that $\mathrm{PKC} \alpha$ is mediating a pro-survival signal in Ishikawa endometrial cancer cells, such that inhibition of PKC $\alpha$ induces apoptosis and sensitizes cells to etoposide treatment.

We next determined changes in $\operatorname{PKC} \delta$ and $\alpha$ activities in response to an apoptotic stimulus. Immunocomplex kinase assays were used to examine the effect of etoposide on PKC $\delta$ and $\alpha$ activities in Ishikawa cells. As shown in Fig. 6A, in response to etoposide treatment, $\mathrm{PKC} \delta$ kinase activity is rapidly increased within $15 \mathrm{~min}$, reaching a maximum level at $30 \mathrm{~min}$, and remains moderately elevated at $2 \mathrm{~h}$. Conversely, PKC $\alpha$ activity apparently decreases over this same period of time, reaching a nadir at $30 \mathrm{~min}$ and remaining below basal levels at the $2 \mathrm{~h}$ time point (Fig. 6B). Western blot analysis confirmed uniform $\mathrm{PKC} \alpha$ and $\delta$ loadings in the kinase assay. No histone kinase activity was detected in control immunoglobulin immunoprecipitates.

The activation of PKCs is frequently associated with the movement from cytosol to membrane fractions and translocation is used as an indirect assessment of activity (Mackay \& Mochly-Rosen 2001). To correlate the apparent etoposide-induced changes in PKC kinase activity with translocation, lysates of Ishikawa cells were fractionated by differential centrifugation as described previously (Jackson et al. 2001), and the soluble and the particulate fractions probed for PKC $\alpha$ and $\delta$. Under basal conditions, the majority of PKC $\delta$ protein $(\sim 75 \%)$ was localized to the particulate fraction in untreated cells (Fig. 7A). While TPA treatment resulted in translocation from soluble to membrane fractions, somewhat surprisingly, etoposide induced a small but significant transient increase in PKC $\delta$ in cytosolic fractions (Fig. 7A). This rapid cytosolic translocation of PKC $\delta$ in response to etoposide occurred over a similar time course to that of the elevated kinase activity (Fig. 6A). Such stimulusspecific translocation of $\mathrm{PKC} \delta$ to the cytoplasm has been reported previously and may reflect the formation of activated lipid-independent kinase activity (Rybin et al. 2004, Yang et al. 2006).

In contrast, $\mathrm{PKC} \alpha$ was predominantly $(\sim 85 \%)$ localized in the soluble fraction (Fig. 7B). Consistent

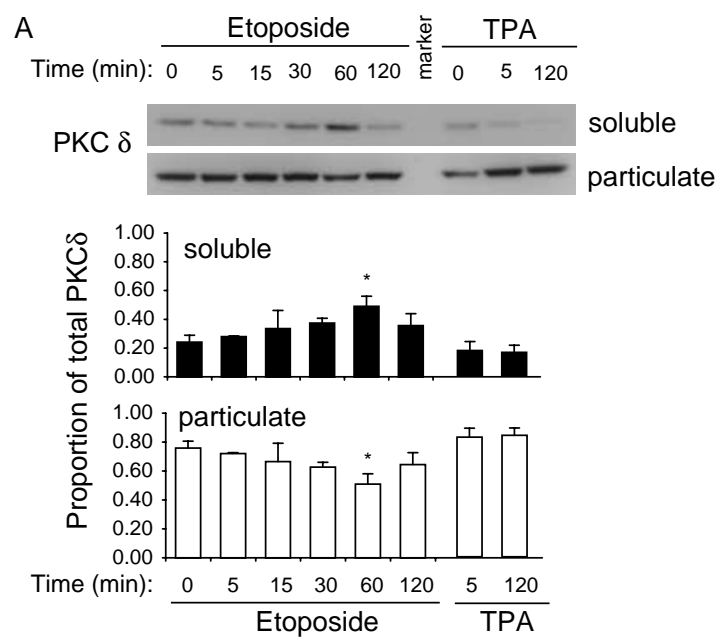

B
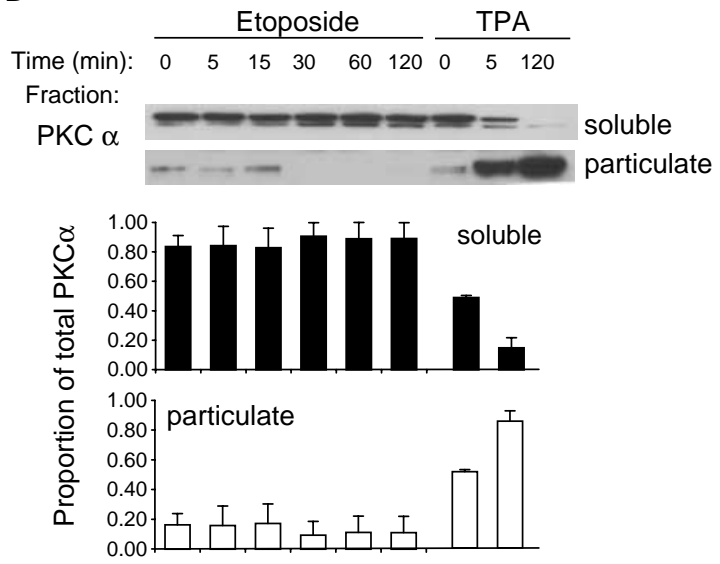

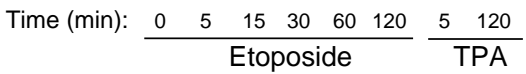

Figure 7 Translocation of $\mathrm{PKC} \delta$ and $\alpha$ following etoposide treatment. Lysates from Ishikawa cells treated with $50 \mu \mathrm{M}$ etoposide, or $100 \mathrm{nM}$ TPA (positive control) were harvested in detergent-free buffer, sonicated, and centrifuged at $70000 \mathrm{~g}$ for $1.5 \mathrm{~h}$. The soluble fraction (supernatant) was collected and the remaining pellet was resuspended and sonicated in buffer containing $1.0 \%$ Triton $\mathrm{X}-100$ to create the Triton-soluble, particulate fraction. Western blotting of particulate and soluble fractions indicates the relative amount of PKC $\delta(A)$ or PKC $\alpha$ (B) protein in each fraction following treatment. The band intensities were determined by densitometry and proportions shown in bar graphs represent the band intensity from one fraction divided by the sum total band intensity of the two fractions. Values are mean \pm S.E.M. from three separate experiments ${ }^{\star} P<0.05$.

with the reduction in kinase activity (Fig. 6B), etoposide treatment resulted in a complete loss of $\mathrm{PKC} \alpha$ from the particulate fraction and a corresponding increase in soluble enzyme. Treatment with the phorbol ester TPA, a known activator of PKC $\alpha$ (Ohno et al. 1991), resulted in a rapid and robust translocation to the particulate fraction (Fig. 7B). Thus, taken together, these results are consistent with $\mathrm{PKC} \delta$ 


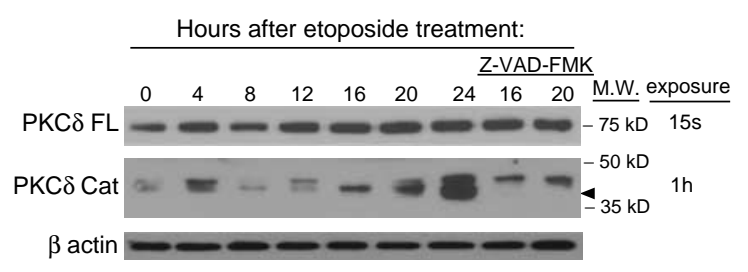

Figure 8 Full-length PKC $\delta$ protein is cleaved by active caspases. Time course of Ishikawa cells treated with $50 \mu \mathrm{M}$ etoposide in combination with $10 \mu \mathrm{M}$ of the general caspase inhibitor, Z-VAD-FMK. A western blot of $20 \mu \mathrm{g}$ of total cellular protein using a $\mathrm{PKC} \delta$-specific antibody is shown at an exposure time of $15 \mathrm{~s}$ (top) or the same blot exposed for $1 \mathrm{~h}(1 \mathrm{~h}$; bottom). Both full-length $\mathrm{PKC} \delta$ protein (PKC $\delta \mathrm{FL}, 75 \mathrm{kDa}$ ) and a $\mathrm{PKC} \delta$ catalytic fragment (PKC $\delta$ Cat, $40 \mathrm{kDa}$ ) sensitive to Z-VAD-FMK (denoted by the arrow) were apparent. For each western blot, a standard marker was used to approximate molecular weight and $\beta$-actin was used to confirm uniform protein loading.

being activated in response to an apoptotic stimulus, while the activity of PKC $\alpha$ is concomitantly decreased.

Recent evidence from other cell types suggests that $\mathrm{PKC} \delta$ is not only a mediator, but also a target of the apoptotic pathway. In cells undergoing apoptosis, PKC $\delta$ can undergo caspase-dependent proteolytic cleavage, between the regulatory and the catalytic domains, releasing a catalytically active fragment (Emoto et al. 1995, Mizuno et al. 1997, Denning et al. 1998, Reyland et al. 1999). To determine if PKC $\delta$ is a target of caspases in endometrial cancer cells, lysates from etoposide-treated Ishikawa cells were harvested over a 24-h time course and probed for PKC $\delta$ protein using an antibody that recognizes an epitope in the C-terminal catalytic domain. As shown in Fig. 8, a $40 \mathrm{kDa}$ band (indicated by the arrow), consistent with the previously reported size of the PKC $\delta$ catalytic fragment, increases in abundance over time in response to etoposide. It is important to note that this band is only detectable after a prolonged exposure of the Western blot, and therefore seems to represent a relatively small fraction of the total PKC $\delta$ protein in the cell. Treatment of Ishikawa cells with the caspase inhibitor, Z-VAD-FMK, blocked the formation of $40 \mathrm{kDa}$ catalytic fragment indicating that cleavage of PKC $\delta$ is caspase-dependent (Fig. 8). A second minor band migrating at higher molecular weight was observed with varying intensity in some samples and was not suppressed by inhibition of caspases. Treatment with Z-VAD-FMK alone had no effect on fulllength or cleaved PKC $\delta$ levels (data not shown).

In summary, we have demonstrated that $\mathrm{PKC} \alpha$ and $\delta$ can differentially regulate endometrial cancer cell survival and apoptosis. PKC $\delta$ is a critical component of the apoptotic pathway in Ishikawa cells, whereas $\mathrm{PKC} \alpha$ activity is required for cell survival.
Accordingly, etoposide treatment and induction of apoptosis resulted in activation and caspase-dependent cleavage of PKC $\delta$ accompanied by a reduction in PKC $\alpha$ kinase activity. Thus, the balance of PKC $\alpha$ and $\delta$ expression and/or activities may be important in the survival of endometrial cancer cells and modulate response to chemotherapeutic agents.

\section{Discussion}

In the endometrium, apoptosis plays a critical role in normal menstrual cycle physiology and is regulated in response to estrogen and progesterone (Arends 1999). Aberrant apoptosis was present in dysfunctional uterine bleeding (Stewart et al. 1999) and increasing cellular apoptosis was observed upon progression from endometrial hyperplasia through atypia to adenocarcinoma (Ioffe et al. 1998). Moreover, undifferentiated and poorly differentiated endometrial carcinomas paradoxically exhibited higher apoptotic indices when compared with well-differentiated tumors; these high indices correlated inversely with prognosis (Heatley 1995, Kokawa et al. 2001b). The highest rates of apoptosis were observed in the rare but aggressive papillary serous and clear cell endometrial carcinomas, characterized by late-stage presentation, extra-uterine invasion, and poor prognosis (Kokawa et al. 2001a). Thus, increased rates of apoptosis have been proposed to be an early morphological indicator of progressively abnormal endometrial growth (Arends 1999, Stewart et al. 1999, Kokawa et al. 2001a).

Differential overexpression of PKC isoforms has also been implicated in endometrial tumor pathogenesis and patient prognosis (Bamberger et al. 1996, 1997, 1998, Tonetti et al. 1998, 2000, Wu et al. 2005), and members of the PKC family have been shown to regulate apoptosis in a variety of other epithelial cell types and tumors (Musashi et al. 2000, Mandil et al. 2001, Brodie \& Blumberg 2003). In general, PKC $\alpha$ appears to suppress or protect against apoptosis (Whelan \& Parker 1998, Li et al. 1999, Deng et al. 2001), while the majority of studies show PKC $\delta$ involvement in the induction of programmed cell death (Basu 2003, Brodie \& Blumberg 2003, Gutcher et al. 2003). However, despite evidence that aberrant apoptosis and PKC isoform expression are phenotypic markers of carcinogenesis and tumor progression in the endometrium, the role of PKC in the regulation of apoptosis in endometrial tumors has not been elucidated.

In this study, we demonstrate, for the first time, a potential mechanistic link between the reported altered PKC expression/activity and aberrant apoptosis 
characteristic of endometrial tumors and suggest a functional role for specific PKC isoforms in the pathogenesis of endometrial cancer. We show that PKC $\alpha$ and $\delta$ differentially modulate apoptosis in endometrial cancer cells, such that $\mathrm{PKC} \delta$ is required for etoposide-induced cell death, while $\mathrm{PKC} \alpha$ is a critical component of a cell survival pathway. Thus, inhibition of PKC $\delta$ confers resistance to the chemotherapeutic drug etoposide (Figs 3 and 4), whereas inhibition of PKC $\alpha$ is sufficient to induce apoptosis and sensitize cells to a genotoxic insult (Figs 3 and 5). Conversely, overexpression of PKC $\delta$ increased basal levels of apoptosis and enhanced the effect of etoposide (Fig. 4). Consistent with these observations, treatment with etoposide and induction of apoptosis resulted in the activation of $\mathrm{PKC} \delta$ and the concomitant inhibition of $\mathrm{PKC} \alpha$ (Fig. 6). While inhibition of PKC $\alpha$ or expression of a dominant-negative construct induced apoptosis and potentiated the response to etoposide, overexpression of wild-type PKC $\alpha$ did not confer resistance to etoposide-induced cell death (Fig. 5). These data suggest that, while PKC $\alpha$ is a critical component of a cell survival pathway in Ishikawa cells, it may not act directly to antagonize apoptotic signals. Our results indicate that relative expressions and/or activities of PKC $\alpha$ and $\delta$ can modulate apoptosis and survival in endometrial cancer cells and that isoformspecific PKC signaling pathways may be important in endometrial tumorigenesis. These studies focus on $\operatorname{PKC} \alpha$ and $\delta$, the principal isoforms implicated in the regulation of apoptosis. However, Ishikawa cells express additional PKCs (Fig. 1), which have also been shown to modulate cell survival and apoptosis (Musashi et al. 2000, Gutcher et al. 2003). Whilst only $\mathrm{PKC} \alpha$ expression has been shown to correlate with patient prognosis and response to hormonal therapy (Tonetti et al. 1998, 2000), the functional role of these additional PKC isoforms remains to be established.

The mechanism by which PKCs modulate apoptosis in the endometrium remains to be established. However, aberrant expression of Bcl-2 proteins in endometrial cancers is associated with increased malignancy and poor prognosis (Ioffe et al. 1998, Ouyang et al. 1998, Sakuragi et al. 2002). Decreased levels of the anti-apoptotic Bcl-2 and upregulation of its pro-apoptotic partner Bax, correlate with increased apoptosis and progression from hyperplasia to malignancy in the endometrium (Chieng et al. 1996, Henderson et al. 1996, Kuwashima et al. 1996, Saegusa et al. 1996, Mozzetti et al. 2000, Kokawa et al. 2001b, Peiro et al. 2001, Sakuragi et al. 2002). $\mathrm{PKC} \alpha$ has been shown to phosphorylate Bcl-2, which may be required for optimal anti-apoptotic function
(Ruvolo et al. 1998, Deng et al. 2001). Similarly, the tumor suppressor PTEN is a negative regulator of PI3-kinase/Akt prosurvival signal transduction pathway (Kennedy et al. 1997, Vazquez \& Sellers 2000) that is frequently mutated or downregulated in endometrial tumors (Maxwell et al. 1998, Ali 2000, Mutter et al. 2000). Ishikawa cells do not express functional PTEN protein (Wan et al. 2002), resulting in constitutive phosphorylation and activation of Akt (Lilja et al. 2001). The present evidence indicates that $\mathrm{PKC} \alpha$ and $\delta$ can be both regulators and targets of the PI3K/Akt signaling pathway regulating cell survival (Mandil et al. 2001, Brodie \& Blumberg 2003, Lu et al. 2004, Greco et al. 2006). PI3K-dependent activation of $\mathrm{PKC} \delta$ is an important mediator of invasion of mammary epithelial cells (Woods Ignatoski et al. 2003) and Akt modulates antiapoptotic PKC $\alpha$ signaling in breast cancer cells. Conversely, PKCs have been shown to modulate PI3k-dependent signal transduction (Wen et al. 2003). PKC $\alpha$ typically stimulates Akt phosphorylation and activity, while $\mathrm{PKC} \delta$ has been shown to induce dephosphorylation and inactivation of Akt in a variety of cell types (Mao et al. 2000, Li et al. 2004, 2006, Zhu et al. 2004). In LNCap prostate cancer cells, which, like endometrial cancers, lack functional PTEN, both PKC $\alpha$ and $\delta$ activation results in dephosphorylation of Akt and induction of apoptosis (Tanaka et al. 2003). We did not detect changes in the levels or phosphorylation states of Akt in response to overexpression or inhibition of $\mathrm{PKC} \delta$ in Ishikawa cells (data not shown). However, potential interactions between the PTEN/Akt and PKC-dependent signaling pathways in endometrial cancer cells remain to be investigated.

The characterization of the functional roles of specific PKC isoforms in endometrial cancer cells may provide new diagnostic or prognostic markers to identify aggressive, malignant tumors and provide a rational basis for novel therapeutic strategies based upon PKC modulating drugs presently under development (Carter 2000, Goekjian \& Jirousek 2001, Hofmann 2004). Given the differential effects of PKC $\alpha$ and $\delta$ in endometrial cancer cells reported herein, such approaches require the development of isoform-specific PKC activators or inhibitors.

\section{Acknowledgements}

We thank Drs Mary Reyland, Arthur GutierrezHartmann, William Wood, and John Tentler for critical reading of this manuscript and Dr Ken Shroyer (Department of Pathology, UCHSC) for assistance with immunohistochemistry staining. 


\section{Funding}

This work was supported by NCI-CA10487 and the University of Colorado Department of Obstetrics \& Gynecology. The authors have no conflicts of interest.

\section{References}

Ali IU 2000 Gatekeeper for endometrium: the PTEN tumor suppressor gene. Journal of the National Cancer Institute 92 861-863.

Arends M 1999 Apoptosis in the endometrium. Histopathology 35 174-178.

Bamberger AM, Bamberger CM, Wald M, Kratzmeier M \& Schulte HM 1996 Protein kinase C (PKC) isoenzyme expression pattern as an indicator of proliferative activity in uterine tumor cells. Molecular and Cellular Endocrinology 123 81-88.

Bamberger AM, Bamberger CM, Wald M, Jensen K \& Schulte HM 1997 PKC isoenzyme expression and cellular responses to phorbol ester in JEG- 3 choriocarcinoma cells. Endocrine 6 111-116.

Bamberger AM, Bamberger CM \& Schulte HM 1998 Molecular mechanisms of proliferation in endometrial tumour cells. Human Reproduction Update 4 526-531.

Basu A 2003 Involvement of protein kinase C-delta in DNA damage-induced apoptosis. Journal of Cellular and Molecular Medicine 7 341-350.

Brodie C \& Blumberg PM 2003 Regulation of cell apoptosis by protein kinase c delta. Apoptosis 8 19-27.

Carpenter L, Cordery D \& Biden TJ 2002 Inhibition of protein kinase $\mathrm{C}$ delta protects rat INS-1 cells against interleukin-1beta and streptozotocin-induced apoptosis. Diabetes 51 317-324.

Carter CA 2000 Protein kinase C as a drug target: implications for drug or diet prevention and treatment of cancer. Current Drug Targets 1 163-183.

Chen Q, Yano T, Matsumi H, Osuga Y, Yano N, Xu J, Wada O, Koga K, Fujiwara T, Kugu K et al. 2005 Cross-Talk between Fas/Fas ligand system and nitric oxide in the pathway subserving granulosa cell apoptosis: a possible regulatory mechanism for ovarian follicle atresia.

Endocrinology 146 808-815.

Chieng DC, Ross JS \& Ambros RA 1996 Bcl-2 expression and the development of endometrial carcinoma. Modern Pathology 9 402-406.

Clemens MJ, Trayner I \& Menaya J 1992 The role of protein kinase $\mathrm{C}$ isoenzymes in the regulation of cell proliferation and differentiation. Journal of Cell Science 103 881-887.

Connor P, Talavera F, Kang JS, Burke J, Roberts J \& Menon KM 1997 Epidermal growth factor activates protein kinase C in the human endometrial cancer cell line HEC-1-A. Gynecologic Oncology 67 46-50.

Cornford P, Evans J, Dodson A, Parsons K, Woolfenden A, Neoptolemos J \& Foster CS 1999 Protein kinase C isoenzyme patterns characteristically modulated in early prostate cancer. American Journal of Pathology 154 137-144.

Cross TG, Scheel-Toellner D, Henriquez NV, Deacon E, Salmon M \& Lord JM 2000 Serine/threonine protein kinases and apoptosis. Experimental Cell Research 256 34-41.

Dai D, Wolf DM, Litman ES, White MJ \& Leslie KK 2002 Progesterone inhibits human endometrial cancer cell growth and invasiveness: down-regulation of cellular adhesion molecules through progesterone B receptors. Cancer Research 62 881-886.

Davies SP, Reddy H, Caivano M \& Cohen P 2000 Specificity and mechanism of action of some commonly used protein kinase inhibitors. Biochemical Journal 351 95-105.

Deng X, Kornblau SM, Ruvolo PP \& May WS Jr 2001 Regulation of $\mathrm{Bcl} 2$ phosphorylation and potential significance for leukemic cell chemoresistance. Journal of the National Cancer Institute. Monographs 28 30-37.

Denning MF, Wang Y, Nickoloff BJ \& Wrone-Smith T 1998 Protein kinase $\mathrm{C}$ delta is activated by caspase-dependent proteolysis during ultraviolet radiation-induced apoptosis of human keratinocytes. Journal of Biological Chemistry 273 29995-30002.

Emoto Y, Manome Y, Meinhardt G, Kisaki H, Kharbanda S, Robertson M, Ghayur T, Wong WW, Kamen R, Weichselbaum R et al. 1995 Proteolytic activation of protein kinase $\mathrm{C}$ delta by an ICE-like protease in apoptotic cells. EMBO Journal 14 6148-6156.

Fishman DD, Segal S \& Livneh E 1998 The role of protein kinase $\mathrm{C}$ in $\mathrm{G} 1$ and $\mathrm{G} 2 / \mathrm{M}$ phases of the cell cycle (Review). International Journal of Oncology 12 181-186.

Fournier DB, Chisamore M, Lurain JR, Rademaker AW, Jordan VC \& Tonetti DA 2001 Protein kinase C alpha expression is inversely related to ER status in endometrial carcinoma: possible role in AP-1-mediated proliferation of ER-negative endometrial cancer. Gynecologic Oncology 81 366-372.

Fujimoto J, Hori M, Ichigo S, Morishita S \& Tamaya T 1995 Clinical implication of fos and jun expressions and protein kinase activity in endometrial cancers. European Journal of Gynaecological Oncology 16 138-146.

Fujimoto J, Hori M, Ichigo S, Morishita S \& Tamaya T 1996 Estrogen induces expression of c-fos and c-jun via activation of protein kinase $\mathrm{C}$ in an endometrial cancer cell line and fibroblasts derived from human uterine endometrium. Gynecological Endocrinology 10 109-118.

Goekjian PG \& Jirousek MR 2001 Protein kinase C inhibitors as novel anticancer drugs. Expert Opinion on Investigational Drugs 10 2117-2140.

Gomez DE, Skilton G, Alonso DF \& Kazanietz MG 1999 The role of protein kinase $\mathrm{C}$ and novel phorbol ester receptors in tumor cell invasion and metastasis (Review). Oncology Reports 6 1363-1370. 
Goodnight J, Mischak H \& Mushinski JF 1994 Selective involvement of protein kinase $\mathrm{C}$ isozymes in differentiation and neoplastic transformation. Advances in Cancer Research 64 159-209.

Greco S, Storelli C \& Marsigliante S 2006 Protein kinase C (PKC)-delta/-epsilon mediate the PKC/Akt-dependent phosphorylation of extracellular signal-regulated kinases 1 and 2 in MCF-7 cells stimulated by bradykinin. Journal of Endocrinology 188 79-89.

Gretz HF, III, Talavera F, Connor P, Pearl M, Lelle RJ, Roberts JA \& Menon KM 1994 Protein kinase C-dependent and -independent pathways mediate epidermal growth factor (EGF) effects in human endometrial adenocarcinoma cell line KLE. Gynecologic Oncology 53 228-233.

Gschwendt M, Muller HJ, Kielbassa K, Zang R, Kittstein W, Rincke G \& Marks F 1994 Rottlerin, a novel protein kinase inhibitor. Biochemical and Biophysical Research Communications 199 93-98.

Gutcher I, Webb PR \& Anderson NG 2003 The isoformspecific regulation of apoptosis by protein kinase C. Cellular and Molecular Life Sciences 60 1061-1070.

Heatley MK 1995 Association between the apoptotic index and established prognostic parameters in endometrial adenocarcinoma. Histopathology 27 469-472.

Heatley MK 1997 A high apoptotic index occurs in subtypes of endometrial adenocarcinoma associated with a poor prognosis. Pathology 29 272-275.

Henderson GS, Brown KA, Perkins SL, Abbott TM \& Clayton F 1996 Bcl-2 is down-regulated in atypical endometrial hyperplasia and adenocarcinoma. Modern Pathology 9 430-438.

Hofmann J 2004 Protein kinase C isozymes as potential targets for anticancer therapy. Current Cancer Drug Targets 4 125-146.

Ioffe OB, Papadimitriou JC \& Drachenberg CB 1998 Correlation of proliferation indices, apoptosis, and related oncogene expression (bcl-2 and c-erbB-2) and p53 in proliferative, hyperplastic, and malignant endometrium. Human Pathology 29 1150-1159.

Jackson TA, Schweppe RE, Koterwas DM \& Bradford AP 2001 Fibroblast growth factor activation of the rat PRL promoter is mediated by PKCdelta. Molecular Endocrinology 15 1517-1528.

Jaken S 1996 Protein kinase C isozymes and substrates. Current Opinion in Cell Biology 8 168-173.

Jemal A, Murray T, Ward E, Samuels A, Tiwari RC, Ghafoor A, Feuer EJ \& Thun MJ 2005 Cancer statistics, 2005. CA: $a$ Cancer Journal for Clinicians 55 10-30.

Keenan C, Goode N \& Pears C 1997 Assay to determine the isoform specificity of protein kinase $\mathrm{C}$ inhibitors.

Biochemical Society Transactions 25 S591.

Kennedy SG, Wagner AJ, Conzen SD, Jordan J, Bellacosa A, Tsichlis PN \& Hay N 1997 The PI 3-kinase/Akt signaling pathway delivers an anti-apoptotic signal. Genes and Development 11 701-713.
Kiley SC, Welsh J, Narvaez CJ \& Jaken S 1996 Protein kinase $\mathrm{C}$ isozymes and substrates in mammary carcinogenesis. Journal of Mammary Gland Biology and Neoplasia 1 177-187.

Koivunen J, Aaltonen V \& Peltonen J 2006 Protein kinase C (PKC) family in cancer progression. Cancer Letters 235 1-10.

Kokawa K, Shikone T, Otani T, Nishiyama R, Ishii Y, Yagi S \& Yamoto M 2001a Apoptosis and the expression of Bcl-2 and Bax in patients with endometrioid, clear cell, and serous carcinomas of the uterine endometrium. Gynecologic Oncology 81 178-183.

Kokawa K, Shikone T, Otani T, Nishiyama R, Ishii Y, Yagi S \& Yamoto M 2001b Apoptosis and the expression of Bax and Bcl-2 in hyperplasia and adenocarcinoma of the uterine endometrium. Human Reproduction 16 2211-2218.

Kuwashima Y, Kobayashi Y, Kawarai A, Uehara T, Kurosumi M, Tanuma J, Shiromizu K, Matsuzawa M \& Kishi K 1996 Expression of bcl-2 and apoptotic DNA fragmentation in human endometrial adenocarcinoma cells. Anticancer Research 16 3221-3224.

Leslie K, Kumar N, Richer J, Owen G, Takimoto G, Horwitz K \& Lange C 1997 Differential expression of the A and B isoforms of progesterone receptor in human endometrial cancer cells. Annals of the New York Academy of Sciences 828 17-26.

Leszczynski D 1995 Regulation of cell cycle and apoptosis by protein kinase $\mathrm{C}$ in rat myeloid leukemia cell line. Oncology Research 7 471-480.

Li W, Zhang J, Flechner L, Hyun T, Yam A, Franke TF \& Pierce JH 1999 Protein kinase C-alpha overexpression stimulates Akt activity and suppresses apoptosis induced by interleukin 3 withdrawal. Oncogene 18 6564-6572.

Li J, Dokka S, Wang L, Shi X, Castranova V, Yan Y, Costa M \& Huang C 2004 Activation of aPKC is required for vanadate-induced phosphorylation of protein kinase $\mathrm{B}$ (Akt), but not p70S6k in mouse epidermal JB6 cells. Molecular and Cellular Biochemistry 255 217-225.

Li L, Sampat K, Hu N, Zakari J \& Yuspa SH 2006 Protein kinase $\mathrm{C}$ negatively regulates Akt activity and modifies UVC-induced apoptosis in mouse keratinocytes. Journal of Biological Chemistry 281 3237-3243.

Lilja JF, Wu D, Reynolds RK \& Lin J 2001 Growth suppression activity of the PTEN tumor suppressor gene in human endometrial cancer cells. Anticancer Research 21 1969-1974.

Lu D, Huang J \& Basu A 2004 Deregulation of PKB influences antiapoptotic signaling by PKC in breast cancer cells. International Journal of Oncology 25 671-676.

Lucas M \& Sanchez-Margalet V 1995 Protein kinase C involvement in apoptosis. General Pharmacology 26 881-887.

Mackay K \& Mochly-Rosen D 2001 Localization, anchoring, and functions of protein kinase $\mathrm{C}$ isozymes in the heart. Journal of Molecular and Cellular Cardiology 33 1301-1307. 
Mandil R, Ashkenazi E, Blass M, Kronfeld I, Kazimirsky G, Rosenthal G, Umansky F, Lorenzo PS, Blumberg PM \& Brodie C 2001 Protein kinase C alpha and protein kinase $\mathrm{C}$ delta play opposite roles in the proliferation and apoptosis of glioma cells. Cancer Research $\mathbf{6 1}$ 4612-4619.

Mao M, Fang X, Lu Y, Lapushin R, Bast RC Jr \& Mills GB 2000 Inhibition of growth-factor-induced phosphorylation and activation of protein kinase B/Akt by atypical protein kinase $\mathrm{C}$ in breast cancer cells. Biochemical Journal 352 475-482.

Maxwell GL, Risinger JI, Gumbs C, Shaw H, Bentley RC, Barrett JC, Berchuck A \& Futreal PA 1998 Mutation of the PTEN tumor suppressor gene in endometrial hyperplasias. Cancer Research 58 2500-2503.

Mizuno K, Noda K, Araki T, Imaoka T, Kobayashi Y, Akita Y, Shimonaka M, Kishi S \& Ohno S 1997 The proteolytic cleavage of protein kinase $\mathrm{C}$ isotypes, which generates kinase and regulatory fragments, correlates with Fas-mediated and 12-O- tetradecanoyl-phorbol-13acetate-induced apoptosis. European Journal of Biochemistry 250 7-18.

Morse-Gaudio M, Connolly JM \& Rose DP 1998 Protein kinase $\mathrm{C}$ and its isoforms in human breast cancer cells: relationship to the invasive phenotype. International Journal of Oncology 12 1349-1354.

Mozzetti S, Ferrandina G, Marone M, D'Ingiullo F, Fruscella E, De Pasqua A, Mancuso S \& Scambia G 2000 Expression of bcl-2, bax-xL, and bcl-xS in endometrial and cervical tissues. Cancer Detection and Prevention 24 536-541.

Mpoke SS \& Wolfe J 1997 Differential staining of apoptotic nuclei in living cells: application to macronuclear elimination in Tetrahymena. Journal of Histochemistry and Cytochemistry 45 675-683.

Musashi M, Ota S \& Shiroshita N 2000 The role of protein kinase $\mathrm{C}$ isoforms in cell proliferation and apoptosis. International Journal of Hematology 72 12-19.

Mutter GL, Lin MC, Fitzgerald JT, Kum JB, Baak JP, Lees JA, Weng LP \& Eng C 2000 Altered PTEN expression as a diagnostic marker for the earliest endometrial precancers. Journal of the National Cancer Institute 92 924-930.

Newton AC 2001 Protein kinase C: structural and spatial regulation by phosphorylation, cofactors, and macromolecular interactions. Chemical Reviews 101 2353-2364.

Nishida M, Kasahara K, Oki A, Satoh T, Arai Y \& Kubo T 1996 Establishment of eighteen clones of Ishikawa cells. Human Cell 9 109-116.

Nishikawa K, Toker A, Johannes F-J, Songyan Z \& Cantley L 1997 Determination of the specific substrate sequence motifs of protein kinase C isozymes. Journal of Biological Chemistry 272 952-960.

Ohno S, Akita Y, Hata A, Osada S, Kubo K, Konno Y, Akimoto K, Mizuno K, Saido T, Kuroki T et al. 1991 Structural and functional diversities of a family of signal transducing protein kinases, protein kinase $\mathrm{C}$ family; two distinct classes of PKC, conventional $\mathrm{cPKC}$ and novel nPKC. Advances in Enzyme Regulation 31 287-303.

Ouyang H, Furukawa T, Abe T, Kato Y \& Horii A 1998 The BAX gene, the promoter of apoptosis, is mutated in genetically unstable cancers of the colorectum, stomach, and endometrium. Clinical Cancer Research 4 1071-1074.

Peiro G, Diebold J, Baretton GB, Kimmig R \& Lohrs U 2001 Cellular apoptosis susceptibility gene expression in endometrial carcinoma: correlation with Bcl-2, Bax, and caspase-3 expression and outcome. International Journal of Gynecological Pathology 20 359-367.

Poplin EA, Liu PY, Delmore JE, Wilczynski S, Moore DF Jr, Potkul RK, Fine BA, Hannigan EV \& Alberts DS 1999 Phase II trial of oral etoposide in recurrent or refractory endometrial adenocarcinoma: a southwest oncology group study. Gynecologic Oncology 74 432-435.

Reyland ME, Anderson SM, Matassa AA, Barzen KA \& Quissell DO 1999 Protein kinase C delta is essential for etoposide-induced apoptosis in salivary gland acinar cells. Journal of Biological Chemistry 274 19115-19123.

Reyland ME, Barzen KA, Anderson SM, Quissell DO \& Matassa AA 2000 Activation of PKC is sufficient to induce an apoptotic program in salivary gland acinar cells. Cell Death and Differentiation 7 1200-1209.

Ruvolo PP, Deng X, Carr BK \& May WS 1998 A functional role for mitochondrial protein kinase Calpha in $\mathrm{Bcl} 2$ phosphorylation and suppression of apoptosis. Journal of Biological Chemistry 273 25436-25442.

Rybin VO, Guo J, Sabri A, Elouardighi H, Schaefer E \& Steinberg SF 2004 Stimulus-specific differences in protein kinase $\mathrm{C}$ delta localization and activation mechanisms in cardiomyocytes. Journal of Biological Chemistry 279 19350-19361.

Saegusa M, Kamata Y, Isono M \& Okayasu I 1996 Bcl-2 expression is correlated with a low apoptotic index and associated with progesterone receptor immunoreactivity in endometrial carcinomas. Journal of Pathology 180 275-282.

Sakuragi N, Salah-eldin AE, Watari H, Itoh T, Inoue S, Moriuchi T \& Fujimoto S 2002 Bax, Bcl-2, and p53 expression in endometrial cancer. Gynecologic Oncology 86 288-296.

Soldani C \& Scovassi AI 2002 Poly(ADP-ribose) polymerase-1 cleavage during apoptosis: an update. Apoptosis 7 321-328.

Spitaler M, Wiesenhofer B, Biedermann V, Seppi T, Zimmermann J, Grunicke H \& Hofmann J 1999

The involvement of protein kinase $\mathrm{C}$ isoenzymes alpha, epsilon and zeta in the sensitivity to antitumor treatment and apoptosis induction. Anticancer Research 19 3969-3976.

Stewart C, Campball-Brown M \& Farrquharson M 1999 Endometrial apoptosis in patients with dysfunctional uterine bleeding. Histopathology 34 99-105. 
Tanaka Y, Gavrielides MV, Mitsuuchi Y, Fujii T \& Kazanietz MG 2003 Protein kinase C promotes apoptosis in $\mathrm{LNCaP}$ prostate cancer cells through activation of $\mathrm{p} 38$ MAPK and inhibition of the Akt survival pathway. Journal of Biological Chemistry 278 33753-33762.

Tonetti DA, O'Regan R, Tanjore S, England G \& Jordan VC 1998 Antiestrogen stimulated human endometrial cancer growth: laboratory and clinical considerations. Journal of Steroid Biochemistry and Molecular Biology 65 181-189.

Tonetti DA, Chisamore MJ, Grdina W, Schurz H \& Jordan VC 2000 Stable transfection of protein kinase $C$ alpha cDNA in hormone-dependent breast cancer cell lines. British Journal of Cancer 83 782-791.

Tringler B, Liu W, Corral L, Torkko KC, Enomoto T, Davidson S, Lucia MS, Heinz DE, Papkoff J \& Shroyer KR 2006 B7-H4 overexpression in ovarian tumors. Gynecologic Oncology 100 44-52.

Vazquez F \& Sellers WR 2000 The PTEN tumor suppressor protein: an antagonist of phosphoinositide 3- kinase signaling. Biochimica et Biophysica Acta 1470 M21-M35.

Ventura C \& Maioli M 2001 Protein kinase C control of gene expression. Critical Reviews in Eukaryotic Gene Expression 11 243-267.

Vollmer G 2003 Endometrial cancer: experimental models useful for studies on molecular aspects of endometrial cancer and carcinogenesis. Endocrine-Related Cancer 10 23-42.

Wada T, Pippin JW, Terada Y \& Shankland SJ 2005 The cyclin-dependent kinase inhibitor p21 is required for TGF-beta1-induced podocyte apoptosis. Kidney International 68 1618-1629.

Wan X, Yokoyama Y, Shinohara A, Takahashi Y \& Tamaya T 2002 PTEN augments staurosporine-induced apoptosis in PTEN-null Ishikawa cells by downregulating PI3K/Akt signaling pathway. Cell Death and Differentiation 9 414-420.
Watters DJ \& Parsons PG 1999 Critical targets of protein kinase $\mathrm{C}$ in differentiation of tumour cells. Biochemical Pharmacology 58 383-388.

Wen HC, Huang WC, Ali A, Woodgett JR \& Lin WW 2003 Negative regulation of phosphatidylinositol 3-kinase and Akt signalling pathway by PKC. Cellular Signalling 15 37-45.

Whelan RD \& Parker PJ 1998 Loss of protein kinase C function induces an apoptotic response. Oncogene 16 1939-1944.

Woods Ignatoski KM, Livant DL, Markwart S, Grewal NK \& Ethier SP 2003 The role of phosphatidylinositol $3^{\prime}$-kinase and its downstream signals in erbB-2mediated transformation. Molecular Cancer Research 1 551-560.

Wu H, Chen Y, Liang J, Shi B, Wu G, Zhang Y, Wang D, Li R, Yi X, Zhang H et al. 2005 Hypomethylation-linked activation of PAX2 mediates tamoxifen-stimulated endometrial carcinogenesis. Nature 438 981-987.

Yang D, Guo J, Divieti P \& Bringhurst FR 2006 Parathyroid hormone activates PKC-delta and regulates osteoblastic differentiation via a PLC-independent pathway. Bone 38 485-496.

Yu K, Kennedy CA, O’Neill MM, Barton RW \& Tatake RJ 2001 Disparate cleavage of poly-(ADP-ribose)-polymerase (PARP) and a synthetic tetrapeptide, DEVD, by apoptotic cells. Apoptosis 6 151-160.

Zeidman R, Pettersson L, Sailaja PR, Truedsson E, Fagerstrom S, Pahlman S \& Larsson C 1999 Novel and classical protein kinase $\mathrm{C}$ isoforms have different functions in proliferation, survival and differentiation of neuroblastoma cells. International Journal of Cancer $\mathbf{8 1}$ 494-501.

Zhu D, Jiang X, Wu X, Tian F, Mearow K, Lipsky RH \& Marini AM 2004 Inhibition of protein kinase C promotes neuronal survival in low potassium through an Akt-dependent pathway. Neurotoxicity Research 6 281-289. 